\title{
Gambaran Kualitas Hidup Dewasa Autistik: Studi terhadap Mahasiswa Autistik di Universitas X
}

\author{
MUTHI'AH AMAH AL RAHIM \& IKA YUNIAR CAHYANTI* \\ Departemen Psikologi Klinis dan Kesehatan Mental, Fakultas Psikologi Universitas Airlangga
}

\begin{abstract}
ABSTRAK
Penelitian ini bertujuan mendapatkan gambaran kualitas hidup mahasiswa autistik di Universitas X. Mahasiswa autistik di Universitas X mengalami penolakan dan kesulitan dalam berkomunikasi. Dewasa autistik dengan pengalaman serupa dilaporkan memiliki kualitas hidup lebih rendah, terutama pada kualitas relasi sosial. Penelitian ini menggunakan pendekatan kualitatif dengan metode studi kasus intrinsik. Partisipan penelitian berjumlah tiga mahasiswa dan empat significant other. Data penelitian didapatkan melalui wawancara dengan pedoman terstandar yang terbuka dan dianalisis melalui analisis tematik. Hasil penelitian dilihat melalui empat domain kualitas hidup setiap partisipan. Terdapat partisipan yang memiliki gambaran domain kesehatan fisik yang baik dan kurang baik. Begitu pula pada domain relasi sosial. Kemudian, seluruh partisipan memiliki gambaran domain relasi lingkungan yang baik dan domain psikologis yang kurang baik. Hasil penelitian ini menunjukkan adanya perbedaan gambaran kualitas hidup antar partisipan. Perbedaan terjadi karena setiap partisipan memiliki pengalaman dan pemaknaan yang beragam.
\end{abstract}

Kata kunci: dewasa autistik, kualitas hidup, mahasiswa autistik

\begin{abstract}
This study aims to obtain an overview on the quality of life of autistic students at X University. Autistic students at X University experienced rejection and the inability to communicate well. Autistic adults with similar experiences reported to have lower quality life, especially the quality of their social relationships. This study utilizes a qualitative approach with an intrinsic case study design. The research was conducted on three students and four significant others. The research data was obtained through interviews with open standardized guidelines and analyzed through thematic analysis. The results can be seen through four domains of quality of life per participant. There were participants who had a good and poorer overview of physical health domain. So is the social relationships domain. Then, all participants had a good overview of environmental relationship domain and a poorer psychological domain. The results of this study showed a difference overview of quality of life between participants. The difference occurred because each participant had a variety of experiences and meanings.
\end{abstract}

Keywords: autistic adults, autistic students, quality of life

Buletin Penelitian Psikologi dan Kesehatan Mental (BRPKM), 2021, Vol. 1(1), 280-291

*Alamat korespondensi: Fakultas Psikologi Universitas Airlangga, Kampus B Universitas Airlangga Jalan Airlangga 4-6 Surabaya 60286. Surel: ika.yuniar@psikologi.unair.ac.id 
Naskah ini merupakan naskah dengan akses terbuka dibawah ketentuan the Creative Common Attribution License (CC-BY-4.0) (http://creativecommons.org/licenses/by/4.0), sehingga penggunaan, distribusi, reproduksi dalam media apapun atas artikel ini tidak dibatasi, selama sumber aslinya disitir dengan baik.

\section{PEN D A H U L U A N}

Autism Spectrum Disorder (ASD) merupakan gangguan yang dialami individu pada aspek komunikasi sosial, perilaku sosial, dan keterbatasan minat serta perilaku. Gangguan ini terbagi dalam tingkatan dan rentang tertentu, mulai dari sangat ringan hingga parah. Individu dengan ASD yang kemudian disebut individu autistik diperkirakan semakin meningkat tiap tahunnya, di seluruh belahan dunia (Elsabbagh, dkk., 2012). Diketahui prevalensi ASD secara global sekitar 6,2 per 1.000 orang (Elsabbagh, dkk., 2012). WHO memperkirakan secara global 1 dari 160 anak merupakan anak autistik (World Health Organization, 2018).

Pemerintah belum memiliki data pasti mengenai prevalensi maupun jumlah resmi individu autistik di Indonesia (Kementerian Kesehatan Republik Indonesia, 2016). Hal ini dikarenakan badan kesehatan resmi pemerintah maupun ahli belum pernah melakukan survei atau penelitian guna mengetahui prevalensi anak autistik di Indonesia. Pihak Kementerian Kesehatan mengatakan bahwa saat ini angka kejadian ASD hanya dapat dilihat melalui angka kunjungan di rumah sakit umum dan klinik tumbuh kembang anak yang terdapat di rumah sakit jiwa (Kemenkes RI, 2016). Berdasarkan laporan yang diterima, para terapis, dokter spesialis anak, dokter spesialis jiwa anak, psikolog dan psikiater anak menemukan adanya peningkatan sekitar 3 sampai 5 kasus baru per tahun (Kemenkes RI, 2012). Angka kejadian ASD yang terus meningkat ini menandakan bahwa populasi individu autistik akan semakin besar, mulai usia anak-anak hingga dewasa.

Ketika anak autistik beranjak dewasa, ia tidak lepas dari gejala-gejala autistiknya. Penanganan yang didapatkan di masa anak-anak bukan bertujuan untuk menghilangkan gejala autistik, tetapi membantu anak autistik agar lebih adaptif dan berdaya. Matadjo (2019) menyatakan kondisi individu autistik yang telah beranjak dewasa dapat bermacam-macam. Ada dewasa autistik yang mandiri dan mampu melakukan interaksi sosial dengan baik, ada pula yang sebaliknya. Kondisi ini dipengaruhi oleh tingkat keparahan yang dimiliki, lingkungan keluarga, lingkungan pendidikan, dan terapi yang didapatkan (Matadjo, 2019). Seltzer, dkk. (2004 dalam Bishop-Fitzpatrick, dkk., 2013) pun menyatakan dalam penelitiannya bahwa hanya sedikit sekali dewasa autistik yang hidup mandiri, menikah, berkuliah, bekerja dalam lingkungan kompetitif, atau mengembangkan hubungan sosial yang luas. Selain itu, mayoritas dewasa autistik juga masih tinggal bersama keluarganya atau penyedia layanan profesional.

Penelitian Levy dan Perry (2011) menemukan bahwa rata-rata 50-60\% dewasa autistik meninggalkan sekolah tanpa memiliki keahlian tertentu, 76\% tidak mampu menemukan pekerjaan, dan 90-95\% tidak mampu membangun relasi romantis jangka panjang atau membangun pertemanan yang bermakna. Kondisi ini menyebabkan dewasa autistik sering kali mengalami gangguan depresi dan kecemasan dengan tingkat potensi yang lebih tinggi dari populasi umum dan individu yang memiliki gangguan perkembangan lainnya (Bradley, dkk., 2004; Brereton, dkk., 2006 dalam Bishop-Fitzpatrick, dkk., 2013). Selain itu, kondisi ini juga memberikan pengaruh yang signifikan terhadap kualitas hidup dewasa autistik.

World Health Organization (WHO) mendefinisikan kualitas hidup sebagai persepsi individu terhadap posisinya dalam hidup, pada konteks budaya dan sistem nilai tempat ia tinggal, dan pada tujuan yang 
ingin dicapai, ekspektasi, standar, serta perhatian yang dituju (Harper, 1998 dalam Mason, dkk., 2018). Kualitas hidup meliputi kesehatan fisik individu, status psikologis, tingkat kemandirian, relasi sosial, keyakinan individu (personal beliefs), dan relasi individu dengan hal yang menonjol atau khas pada lingkungannya. Berdasarkan definisi kualitas hidup yang dikembangkan WHO, terdapat 4 domain utama yang membentuk kualitas hidup individu, yaitu kesehatan fisik, psikologis, relasi sosial, dan lingkungan (WHOQOL Group, 1998).

Beberapa penelitian mengenai kualitas hidup dewasa autistik menemukan bahwa dari keempat domain utama kualitas hidup, relasi sosial menjadi domain yang paling umum dipaparkan sebagai domain kualitas hidup terendah pada dewasa autistik (Jennes-Coussens, dkk., 2006; Kamp-Becker, dkk., 2010; Lin, 2014 dalam Mason, dkk., 2018). Dewasa autistik yang memiliki skor rendah pada domain relasi sosial, secara umum melaporkan adanya pengalaman negatif seperti penolakan, ketidakmampuan dalam berkomunikasi dengan baik, dan gagal dalam menjalin relasi romantis. Pengalaman negatif ini kemudian memengaruhi kondisi psikologis dewasa autistik, sehingga skor domain kesehatan psikologis pun akan cenderung rendah juga.

Temuan ini sejalan dengan temuan pada penelitian Moss, dkk. (2017) mengenai kualitas hidup dewasa autistik. Skor kualitas hidup yang diisi oleh partisipan memiliki urutan rerata skor domain kualitas hidup terendah dimulai dari domain relasi sosial dengan rerata skor 69,5, domain kesehatan psikologis 72,1, domain lingkungan 76,6, dan domain kesehatan fisik 81,1 (Moss, dkk., 2017). Faktor yang berpengaruh secara signifikan terhadap kepuasan relasi sosial dewasa autistik adalah kemampuan sosial. Dewasa autistik dengan kemampuan sosial yang rendah, memiliki tingkat kepuasan relasi sosial yang rendah pula.

Secara umum, rerata skor kualitas hidup dewasa autistik lebih rendah dibandingkan dengan orang dewasa lainnya. Hal ini dipengaruhi oleh beberapa faktor seperti tingkat keparahan autisme, kemampuan kognitif, kemampuan komunikasi sosial dan berbahasa, perilaku adaptif, dan kondisi kejiwaan komorbid (Biggs \& Carter, 2016; Chiang \& Wineman, 2014; Hong, dkk., 2016; Ikeda, dkk., 2014; Kamio, dkk., 2013 dalam Moss, dkk., 2017).

Saat ini, pendidikan dan lingkungan inklusif semakin berkembang. Dewasa autistik yang melanjutkan pendidikan ke perguruan tinggi pun meningkat (Jackson, dkk., 2018). Ketika menjadi mahasiswa, dewasa autistik menghadapi tantangan akademik yang lebih besar untuk menyelesaikan perkuliahan (Volkmar, dkk., 2017). Mereka dituntut untuk memiliki kemampuan adaptasi yang baik. Kemampuan adaptasi pada mahasiswa autistik dipengaruhi oleh faktor-faktor nonakademik seperti gangguan relasi sosial, kemampuan komunikasi, tuntutan sosial, perubahan jadwal, dan manajemen kehidupan seharihari (Volkmar, dkk., 2017). Program pendidikan inklusi yang diberikan perguruan tinggi saat ini belum banyak mencakup faktor nonakademik tersebut, sehingga mahasiswa autistik dituntut untuk beradaptasi dengan adanya faktor nonakademik secara mandiri. Ketika mahasiswa autistik tidak dapat beradaptasi dengan baik, mereka cenderung mengalami distres.

Sistematik review terhadap 20 artikel penelitian yang dilakukan oleh Gelbar, dkk. (2014) menemukan bahwa mahasiswa autistik secara umum mengalami kecemasan berlebih, kemudian diikuti dengan adanya kesepian dan depresi. Mereka pun mendeskripsikan adanya pengalaman terisolasi atau terpinggirkan. Ketidakmampuan mahasiswa autistik untuk memenuhi standar di sekitarnya, kurangnya pemahaman mahasiswa sebaya lain mengenai mahasiswa autistik, serta kurangnya penyediaan layanan dan sosialisasi oleh perguruan tinggi, dinilai dapat menciptakan lingkungan yang kurang inklusif, sehingga memunculkan distres bagi mahasiswa autistik. Beberapa peneliti menyarankan konselor pada perguruan tinggi untuk bertindak sebagai fasilitator utama yang mengoordinasi bantuan (support) 
antara fakultas, kantor pelayanan disabilitas, mentor sebaya, dan orang tua (Graetz \& Spampinato, 2008; Pillay \& Bhat, 2012). Selain itu, diperlukan pendalaman terlebih dahulu mengenai mahasiswa autistik guna memahami apa yang dirasakan dan dibutuhkan oleh mereka.

Universitas X merupakan salah satu perguruan tinggi inklusif di Jawa Timur. Universitas X memiliki program pendidikan inklusi yang dibentuk pada tahun 2018. Program ini memberikan pendampingan bagi MBK dalam aspek perkuliahan. Pendampingan dilakukan oleh mahasiswa relawan pendamping resmi. Berdasarkan wawancara yang telah dilakukan penulis terhadap relawan pendamping, pendampingan bersifat kondisional, sesuai dengan kebutuhan setiap MBK. Peran relawan pendamping adalah mendampingi dan membantu dalam hal teknis perkuliahan, bukan substansi perkuliahan.

Berdasarkan wawancara penulis terhadap orang tua mahasiswa autistik di Universitas X, mahasiswa autistik membutuhkan pendampingan akademik. Hal ini dikarenakan nilai mahasiswa autistik banyak yang tidak memenuhi batas minimal. Kemudian, orang tua mahasiswa autistik lainnya mengatakan bahwa mahasiswa autistik lebih membutuhkan pendampingan sosial. Pendampingan sosial diharapkan mampu meningkatkan kemampuan komunikasi sosial mahasiswa autistik dan membantu mereka dalam membangun pertemanan. Sejalan dengan penelitian Shattuck, dkk. (2014), ia menyebutkan bahwa banyak mahasiswa autistik yang membutuhkan bantuan dalam komunikasi sosial dan akomodasi harian.

Pada wawancara yang dilakukan penulis terhadap mahasiswa autistik, terdapat beberapa mahasiswa autistik yang mengatakan kesulitan dalam berkomunikasi sosial. Hal ini dikarenakan adanya keterbatasan dalam memahami dan merespon komunikasi orang lain. Mahasiswa autistik pun mengatakan adanya pengalaman tidak menyenangkan, seperti diacuhkan oleh mahasiswa senior dan dimanfaatkan oleh mahasiswa lain karena ketidakmampuannya dalam memahami situasi sosial yang sedang dihadapi. FR, salah satu mahasiswa autistik Universitas X, mengatakan kepada ibunya bahwa ia ingin bepergian dengan temannya, namun ia tidak pernah diajak.

Beberapa penelitian sebelumnya pun menyebutkan bahwa mahasiswa autistik mengalami kesulitan dalam melakukan komunikasi sosial (Adreon \& Durocher, 2007; Van Hees, dkk., 2015; White, dkk., 2016; Mason, dkk., 2018). Mereka tidak mengetahui respon apa yang perlu ditampakkan ketika berada di situasi sosial tertentu. Selain itu mahasiswa autistik juga mengalami perasaan terkucilkan dan kelelahan berkepanjangan. Mahasiswa autistik pun mengalami berbagai permasalahan kesehatan mental seperti stres, kecemasan berlebih, dan depresi (Adreon \& Durocher, 2007; Van Hees, dkk., 2015). Ketidakmampuan mahasiswa autistik untuk beradaptasi dan menghadapi permasalahan kesehatan mental, memberikan pengaruh yang signifikan terhadap kualitas hidup mahasiswa autistik (Pugliese \& White, 2014; Van Hees, dkk., 2015; White, dkk., 2016). Mahasiswa autistik dilaporkan memiliki kualitas hidup yang lebih rendah dibandingkan dengan kualitas hidup mahasiswa lainnya.

Berdasarkan data yang didapatkan penulis di atas, maka diperlukan penelitian mendalam mengenai kualitas hidup mahasiswa autistik di Universitas X. Penelitian ini dilakukan untuk mencari tahu permasalahan dan kebutuhan mahasiswa autistik melalui berbagai aspek yang membangun tiap domain kualitas hidup mahasiswa autistik. Pengetahuan dan pemahaman mengenai mahasiswa autistik perlu ditingkatkan, sebagai salah satu upaya dalam memahami, menyikapi, dan merencanakan program bagi dewasa autistik yang memerlukan bantuan, terutama pada setting lingkungan perguruan tinggi. Selain itu, melalui pemahaman staf dan mahasiswa sebaya mengenai kebutuhan dan permasalahan yang dihadapi mahasiswa autistik, maka diharapkan mahasiswa autistik di Universitas X menjadi lebih mudah dalam beradaptasi dengan lingkungan perguruan tinggi dan memiliki kualitas hidup yang lebih baik. 


\section{Desain Penelitian}

\section{E T O D E}

Penelitian ini menggunakan pendekatan kualitatif untuk mengkaji secara mendalam pengalaman partisipan. Pendekatan kualitatif memandang gejala permasalahan sebagai suatu fenomena yang utuh atau bersifat holistik, sehingga penulis menetapkan penelitian berdasarkan keseluruhan situasi sosial yang diteliti (Sugiyono, 2015). Keseluruhan situasi sosial mencakup aspek tempat, pelaku, dan aktivitas yang saling berinteraksi. Penelitian kualitatif dapat dibahas melalui beberapa metode, salah satunya metode studi kasus. Menurut Starman (1997 dalam Starman, 2013), studi kasus merupakan istilah yang digunakan dalam mengeksplorasi individu, kelompok, atau fenomena. Studi kasus merupakan deskripsi komprehensif dari kasus individu dan analisisnya berupa karakterisasi kasus dan peristiwa, serta deskripsi proses penemuan fitur-fitur yang merupakan proses penelitian itu sendiri (Mesec, 1998 dalam Starman, 2013). Penelitian ini menggunakan metode studi kasus intrinsik. Metode ini dinilai dapat memberikan pemahaman menyeluruh mengenai kualitas hidup mahasiswa autistik, serta memperkuat pemahaman yang telah diketahui sebelumnya tanpa ada upaya menggeneralisasi.

\section{Partisipan}

Partisipan yang dipilih dalam penelitian ini menggunakan pengambilan sampel dengan kriteria tertentu. Pengambilan sampel dengan cara ini memudahkan penulis dalam mempelajari kasus yang telah ditetapkan. Kriteria partisipan pada penelitian ini adalah: 1) Individu yang pernah didiagnosa memiliki Sindrom Asperger atau Sindrom Autisme menggunakan DSM-IV-TR, atau didiagnosa memiliki Gangguan Spektrum Autisme menggunakan DSM-5, oleh ahli (psikolog dan/atau psikiater); 2) Tahun 2019, individu berada pada rentang usia 16 tahun ke atas; dan 3) Tahun 2019, individu terdaftar dan sedang menempuh pendidikan di Universitas X. Partisipan yang memenuhi kriteria dan bersedia berpartisipasi berjumlah 3 partisipan dengan inisial EP, RA, dan FR. Ketiga partisipan memiliki bidang perkuliahan yang berbeda, yaitu S1 Matematika, S1 Sastra Jepang, dan D3 Ilmu Administrasi Perkantoran. Sebagai upaya dalam memperkaya data, penelitian ini juga melibatkan significant other partisipan dalam pengumpulan data. Significant other yang berpartisipasi adalah orang tua dan teman perkuliahan. Sebelum pengumpulan data, seluruh partisipan, baik mahasiswa autistik maupun significant other diberikan informed consent. Pengumpulan data dibagi menjadi beberapa sesi wawancara dan dilakukan secara terpisah antara mahasiswa autistik dan significant other.

\section{Strategi Pengumpulan Data}

Pengumpulan data yang dilakukan pada penelitian ini menggunakan wawancara. Wawancara dilakukan menggunakan pedoman terstandar yang terbuka. Pedoman terstandar yang terbuka memungkinkan penulis untuk mendapatkan lebih banyak data. Hal ini dikarenakan pertanyaan wawancara dapat berkembang seiring dengan jawaban yang diberikan partisipan. Pedoman wawancara dibuat berdasarkan pertanyaan penelitian. Wawancara dilakukan beberapa kali sebagai upaya memperdalam data serta mempertimbangkan kesanggupan partisipan. Setidaknya, partisipan mahasiswa autistik melakukan proses wawancara sebanyak 2 kali.

\section{Analisis Data}

Penulis menggunakan teknik analisis tematik dalam menganalisis data yang diperoleh. Analisis tematik merupakan proses memberikan kode pada informasi-informasi yang didapatkan, sehingga menghasilkan daftar tema, model tema, atau indikator yang kompleks, atau kualifikasi yang berkaitan dengan tema, maupun gabungan dari hal-hal tersebut (Poerwandari, 2017). Pada analisis tematik yang dilakukan penulis, analisis dilakukan dengan mencari dan mengelompokkan tema yang muncul dan penting dalam menjelaskan suatu fenomena. Penulis mengelompokkan kategori analisis berdasarkan 
pertanyaan penelitian, teori dan penelitian terdahulu, serta data yang didapatkan melalui partisipan dan significant other partisipan (Poerwandari, 2017). Sebagai upaya meningkatkan kredibilitas penelitian, penulis melakukan langkah triangulasi data dan member check. Triangulasi data dilakukan dengan wawancara terhadap significant other partisipan. Member check dilakukan dengan pengonfirmasian data terhadap partisipan, sehingga data yang didapatkan sesuai dengan kondisi partisipan yang sebenarnya.

\section{HAS IL P EN EL IT IAN}

\section{Domain Kesehatan Fisik}

Gambaran domain kesehatan fisik didapatkan melalui beberapa aspek, seperti rasa sakit dan tidak nyaman, energi dan kelelahan, tidur dan istirahat, mobilitas, kegiatan sehari-hari, dan kapasitas kerja. EP dan RA memiliki daya kesehatan tubuh yang baik. Mereka jarang mengalami sakit atau merasa tidak nyaman di bagian badan tertentu. Saat ini EP sedang mengalami pertumbuhan gigi yang tidak normal. Hal ini mengakibatkan rasa nyeri pada gigi dan kesulitan mengunyah makanan. Sedangkan FR memiliki daya kesehatan tubuh yang kurang baik. Ia mudah terkena sakit flu dan demam ketika mengonsumsi minuman dingin. Setiap kali merasa stres, FR pun biasanya juga mengalami demam, diare, dan tidak mampu beraktivitas. Kemudian, ketiga partisipan memiliki minat dalam melakukan berbagai kegiatan sehari-hari maupun kegiatan tertentu, seperti rekreasi. Hal ini dipengaruhi oleh pola tidur yang cukup dan kemampuan berpindah tempat yang mudah.

\section{Domain Psikologis}

Gambaran domain psikologis dapat dilihat melalui beberapa aspek, seperti perasaan positif dan negatif yang dialami, pandangan terhadap kemampuan diri, citra dan penampilan diri, harga diri, dan pengaruh spiritualitas pribadi. EP, RA, dan FR mengalami berbagai perasaan positif dan negatif. Diketahui EP mengalami kecemasan berlebihan terhadap kesehatan. Setiap kali terluka atau sakit, EP akan memegang berulang kali dan memeriksa kondisinya. Pada partisipan RA, diketahui RA memiliki minat yang rendah dalam berkuliah. Hal ini disebabkan RA tidak berkuliah di bidang yang diminatinya. Lain halnya dengan FR, diketahui FR mudah stres dan merasa kesepian. Ketika berkuliah, FR menyatakan bahwa ia tidak pernah diajak pergi oleh teman-temannya. Stres yang dialami FR timbul karena adanya kekhawatiran berlebih terhadap berbagai hal. Meski begitu, EP, RA, dan FR memiliki pandangan yang positif terhadap dirinya, seperti memandang diri sebagai orang yang berguna, memiliki kemampuan belajar dan mengingat yang baik, serta memandang citra diri apa adanya. FR pun diketahui juga merasakan adanya pengaruh positif dari keyakinan yang dianut.

\section{Domain Relasi Sosial}

Gambaran domain relasi sosial didapatkan melalui aspek relasi individu dan dukungan sosial. Diketahui EP merasa puas dengan relasi individu yang dimiliki. Selama berkuliah, kebutuhan akademik EP terpenuhi melalui teman-temannya. Pada partisipan RA dan FR, diketahui mereka merasa sebaliknya. RA dan FR memiliki kualitas relasi sosial yang kurang baik. Mereka mengalami kesulitan dalam berkomunikasi dengan orang lain, sehingga belum memiliki teman dekat. FR pun pernah mengalami pertemanan yang membuatnya tidak nyaman. Di sisi lain, baik EP, RA, dan FR memiliki relasi yang sangat baik dengan keluarga. Mereka banyak menghabiskan waktu di rumah dan bersama keluarga. Dukungan yang dirasakan EP, RA, dan FR sebagian besar berasal dari keluarga dan berupa dukungan psikologis maupun materi. Sedangkan dukungan yang berasal dari teman berupa materi, seperti bantuan dalam mengerjakan tugas, berbagi informasi perkuliahan, dan bantuan akademik lain. 


\section{Domain Lingkungan}

Gambaran domain lingkungan yang nampak pada partisipan dapat dilihat melalui aspek keselamatan dan keamanan fisik, lingkungan rumah, keuangan, peluang mendapatkan informasi, keterampilan baru, dan berekreasi, pelayanan kesehatan umum, serta ketersediaan transportasi. EP, RA, dan FR merasa aman ketika berada di rumah dan kampus. FR menambahkan ia juga merasa aman ketika sendirian di tempat-tempat tersebut. Kemudian, EP, RA, dan FR merasa mampu mengelola keuangan dengan baik, sehingga kebutuhannya tercukupi. Tersedianya fasilitas di rumah ketiga partisipan membuat mereka semakin nyaman berada di rumah. Fasilitas yang dimiliki oleh di rumah memudahkan EP, RA, dan FR dalam mengakses informasi dan keterampilan baru. Akses ini didapatkan melalui internet, buku, TV, dan game. Kemudian, ketiga partisipan juga merasakan mudahnya mengakses transportasi yang dapat digunakan dan pelayanan kesehatan. Dalam hal rekreasi, ketiga partisipan memiliki kesempatan untuk berekreasi, baik di rumah maupun di luar rumah. Rekreasi di rumah dilakukan melalui kegiatan bermain game, membaca buku, menonton TV, dan menghabiskan waktu bersama keluarga. Sedangkan rekreasi di luar rumah dilakukan dengan pergi ke mall, mengelilingi kota, pergi ke luar kota, dan mendatangi tempat wisata.

\section{I S K U S I}

Kualitas hidup merupakan konsep multidimensional mengenai pandangan individu terhadap kesejahteraan fisik, emosi, material, relasi sosial, pengembangan diri, dan determinasi diri (Schalock, 2004 dalam Kamp-Becker, dkk., 2010). Kualitas hidup menjadi evaluasi subjektif dan objektif terhadap kesejahteraan fisik, sosial, emosional, dan material, serta pengembangan dan aktivitas individu sesuai dengan nilai hidup yang dianut. Menurut WHO, kualitas hidup dapat digambarkan melalui empat domain utama, yaitu domain kesehatan fisik, psikologis, relasi sosial, dan lingkungan. Berdasarkan hasil penelitian, pada domain kesehatan fisik, satu mahasiswa autistik memiliki gambaran kualitas kesehatan fisik yang baik, sedangkan dua mahasiswa autistik lainnya kurang baik. Daya kesehatan tubuh yang baik, tidur yang cukup, adanya minat dalam melakukan berbagai aktivitas, mandiri, dan tidak mengalami kesulitan dalam bergerak dan berpindah tempat, merupakan aspek-aspek yang meningkatkan kualitas hidup mahasiswa autistik. Temuan ini sejalan dengan penelitian Hong, dkk. (2016) yang mengungkapkan bahwa dewasa autistik yang mandiri memiliki kualitas hidup yang lebih baik. Kemudian, pada penelitian ini ditemukan bahwa mahasiswa yang sedang mengalami sakit dan mahasiswa yang mengalami sakit secara berkala memiliki kualitas kesehatan fisik yang kurang baik. Hal ini dikarenakan rasa sakit yang dialami kedua mahasiswa beberapa kali menghambat kegiatan seharihari.

Pada domain psikologis, ketiga mahasiswa autistik memiliki gambaran kualitas psikologis yang kurang baik. Terdapat mahasiswa yang mengalami kecemasan berlebihan terhadap kesehatan, mudah stres, kesepian, dan memiliki minat yang rendah dalam berkuliah. Stres dapat timbul karena adanya kekhawatiran berlebih terhadap sesuatu. Selain itu stres juga dapat dialami karena tidak terpenuhinya kebutuhan. Stres yang dialami mahasiswa autistik dapat menurunkan kesehatan fisik dan kesehatan psikologis (Hong, dkk., 2016). Kemudian, melalui penelitian ini diketahui pula bahwa mahasiswa autistik yang mengalami stres juga pernah mengalami kesepian. Pengalaman kesepian muncul ketika berteman dengan mahasiswa sebaya yang berasal dari program studi lain. Kesepian ini dirasakan karena tidak adanya komunikasi sosial yang terbangun dengan baik. Temuan ini sesuai dengan temuan pada penelitian sebelumnya yang menyebutkan bahwa mahasiswa autistik secara umum mengalami kecemasan berlebih, kesepian, dan depresi (Adreon \& Durocher, 2007; Gelbar, dkk., 2014).

Buletin Riset Psikologi dan Kesehatan Mental (BRPKM) 2021, Vol. 1(1), 280-291 
Di samping permasalahan-permasalahan di atas, terdapat aspek-aspek yang meningkatkan kualitas psikologis mahasiswa autistik, seperti regulasi diri yang baik dan pandangan positif terhadap diri. Pengaruh positif spiritualitas pun diketahui memiliki peran dalam meningkatkan kualitas psikologis. Regulasi diri mahasiswa autistik nampak pada kemampuan belajar, berkonsentrasi, mengingat berbagai hal, dan mengontrol diri. Dua mahasiswa mengaku memiliki kemampuan konsentrasi yang baik, sedangkan satu mahasiswa lainnya mengaku memiliki daya ingat yang baik. Temuan ini sejalan dengan penelitian Russell, dkk. (2019), yang mengungkapkan bahwa individu autistik memiliki kemampuan daya ingat dan konsentrasi yang baik dan merasa diuntungkan dengan adanya kemampuan tersebut. Kemudian, pandangan diri yang positif nampak pada pandangan ketiga mahasiswa autistik terhadap harga diri, citra diri, dan penampilan dirinya.

Domain relasi sosial dalam penelitian ini merupakan domain yang meliputi relasi individu dengan orang lain, serta dukungan yang dirasakan. Satu mahasiswa autistik diketahui memiliki gambaran kualitas relasi sosial yang baik. Dua mahasiswa autistik lainnya memiliki gambaran kualitas relasi sosial yang kurang baik. Mahasiswa dengan gambaran kualitas relasi sosial yang baik, memiliki teman dekat dan mendapatkan dukungan dari keluarga dan temannya. Mahasiswa mengaku senang dengan relasi yang dimiliki, karena kebutuhannya terpenuhi. Berdasarkan wawancara yang dilakukan terhadap mahasiswa autistik dan significant other mahasiswa autistik, penulis memandang bahwa mahasiswa tersebut memiliki ketertarikan yang rendah terhadap pertemanan sebaya, sehingga mahasiswa tidak memiliki permasalahan pada kualitas relasi sosialnya. Sebagaimana penelitian sebelumnya, sebagian mahasiswa autistik mengungkapkan bahwa tidak memiliki kebutuhan untuk bertemu dengan orang lain dan membangun pertemanan (Cullen, 2015).

Peneliti menemukan terdapat beberapa permasalahan yang dialami dua mahasiswa autistik dengan gambaran kualitas relasi sosial kurang baik. Permasalahan ini berkaitan dengan gejala autistik yang dimiliki kedua mahasiswa autistik, yaitu gangguan komunikasi sosial. Kedua mahasiswa autistik mengungkapkan bahwa beberapa kali mengalami kesulitan dalam berkomunikasi dengan orang lain. Temuan ini sesuai dengan temuan pada penelitian sebelumnya yang juga mengungkapkan bahwa mahasiswa autistik mengalami kesulitan dalam berkomunikasi (White, dkk., 2016). Dalam penelitian ini, mahasiswa autistik memiliki keterbatasan topik pembicaraan.

Keterbatasan topik pembicaraan yang dialami salah satu mahasiswa autistik membuat mahasiswa autistik berulang kali menanyakan hal yang sama. Pola komunikasi ini menyebabkan adanya kegagalan dalam mempertahankan komunikasi. Meski begitu, mahasiswa autistik tetap berusaha membangun pertemanan dengan caranya sendiri. Ia memanfaatkan media sosial untuk terhubung dengan temantemannya, namun jarang melakukan komunikasi sosial di media sosial. Pola komunikasi yang dilakukan mahasiswa autistik di media sosial pun terbatas pada topik yang sama.

Pada satu mahasiswa autistik lainnya, keterbatasan topik pembicaraan menyulitkan mahasiswa autistik untuk berkomunikasi dengan orang lain di luar lingkar pertemanannya dan orang lain yang berbeda minat. Ketika membangun pertemanan, mahasiswa autistik pun mengaku pernah mengalami pertemanan yang buruk, sebelum akhirnya ia merasa memiliki pertemanan yang baik. Hal ini sesuai dengan penelitian sebelumnya yang mengungkapkan bahwa individu autistik seringkali mengalami trial and error terlebih dahulu sebelum menemukan pertemanan yang membuat mereka nyaman (Sosnowy, dkk., 2018). Meski mahasiswa autistik merasa memiliki pertemanan yang baik, namun ia tidak pernah diajak berkumpul ketika di luar kampus. Mahasiswa autistik juga tidak merasakan adanya dukungan yang diberikan oleh teman-temannya. Hal ini menunjukkan bahwa teman mahasiswa autistik belum merasakan kedekatan dengan mahasiswa autistik, sehingga tidak mengajak mahasiswa autistik 
dalam kegiatan di luar kampus. Temuan ini sesuai dengan temuan penelitian sebelumnya yang mengungkapkan bahwa mahasiswa autistik mengalami penolakan dan isolasi (Gelbar, dkk., 2014).

Berdasarkan gambaran relasi pertemanan yang dimiliki ketiga mahasiswa autistik, penulis melihat bahwa pertemanan yang dimiliki oleh mahasiswa autistik terbatas pada pertemanan di kampus saja. Ketika berada di luar kampus, mahasiswa autistik lebih banyak di rumah dan berinteraksi dengan keluarga, bukan dengan teman-temannya. Komunikasi yang dilakukan dengan teman melalui media sosial pun terbatas pada topik perkuliahan saja. Hal ini menunjukkan bahwa mahasiswa autistik mengalami kesulitan dalam membangun pertemanan yang dekat dengan mahasiswa sebaya. Sebagaimana penelitian Pillay dan Bhat (2012), menunjukkan bahwa salah satu isu yang seringkali dihadapi mahasiswa autistik adalah isu kemampuan komunikasi sosial. Kegagalan dalam berkomunikasi dapat menimbulkan pembatasan hingga penolakan oleh orang lain, terhadap mahasiswa autistik. Sejalan dengan penelitian sebelumnya, banyak individu autistik dan anggota keluarga yang mendeskripsikan pengalaman terabaikan dan tidak dapat berkomunikasi dengan baik ketika bersama orang lain (Cullen, 2015). Hal ini membuat dewasa autistik seringkali kesulitan dalam membangun dan mempertahankan pertemanan (Bottema-Beutel, dkk., 2016; Kuo, dkk., 2013; Muller, dkk., 2008 dalam Sosnowy, dkk., 2018).

Sebagaimana yang telah disebutkan sebelumnya, mahasiswa autistik lebih banyak berinteraksi dengan keluarga. Dua mahasiswa mengaku lebih banyak berkomunikasi dan menghabiskan waktu bersama keluarga, sedangkan satu mahasiswa mengaku memiliki intensitas komunikasi yang sama, baik dengan keluarga maupun teman. Mereka pun mengaku lebih nyaman di rumah dan bersama dengan keluarga. Satu mahasiswa memandang ibunya sebagai pemberi dukungan dan bantuan yang paling banyak. Ketika mengalami masalah, ia sering menceritakan kepada ibunya dan meminta bantuan. Sesuai dengan beberapa penelitian sebelumnya, individu autistik mengatakan bahwa keluarga mereka merupakan sumber utama bagi dukungan sosial mereka (Gulec-Aslan, dkk., 2013; Hurlbutt \& Chalmers, 2002; Krieger, dkk., 2012 dalam DePape \& Lindsay, 2016). Berbagai dukungan yang diberikan keluarga, baik pada segi psikologis dan materi memberikan dampak yang besar bagi gambaran kualitas relasi lingkungan mahasiswa autistik. Ketika mereka merasa terfasilitasi, memiliki peluang, dan merasa aman, maka kualitas relasi lingkungannya akan meningkat.

\section{S I M P U L A N}

Gambaran kualitas hidup mahasiswa autistik di Universitas X dapat dilihat melalui empat domain kualitas hidup, yaitu domain kesehatan fisik, psikologis, relasi sosial, dan lingkungan. Kualitas kesehatan fisik mahasiswa autistik akan meningkat ketika memiliki daya kesehatan tubuh yang baik, waktu tidur yang cukup, berminat dalam melakukan berbagai aktivitas, merasa mandiri, dan tidak mengalami kesulitan dalam bergerak dan berpindah tempat. Namun, ketika mahasiswa autistik sedang sakit maupun memiliki riwayat sakit secara berkala, kualitas kesehatan fisiknya akan menurun. Pada domain psikologis, kualitas psikologis mahasiswa autistik cenderung kurang baik. Kualitas ini menurun ketika mereka mengalami kecemasan berlebihan terhadap kesehatan, mudah stres, kesepian, dan memiliki minat yang rendah dalam berkuliah. Di sisi lain, kualitas psikologis mahasiswa autistik meningkat ketika memiliki regulasi diri yang baik dan pandangan positif terhadap diri. Pada domain relasi sosial, mahasiswa autistik memiliki gambaran kualitas relasi sosial yang baik ketika ketertarikan terhadap pertemanan sebaya rendah dan merasa cukup dengan relasi yang dimiliki. Pada mahasiswa autistik lainnya, kualitas relasi sosial menurun ketika memiliki ketertarikan terhadap pertemanan sebaya, namun mengalami kesulitan dalam melakukan komunikasi dan membangun pertemanan yang dekat dengan mahasiswa sebaya. Meski begitu, mahasiswa autistik memiliki relasi yang dekat dengan

Buletin Riset Psikologi dan Kesehatan Mental (BRPKM) 2021, Vol. 1(1), 280-291 
keluarga dan mendapat dukungan terbesar dari keluarga. Kemudian, pada domain lingkungan, mahasiswa autistik memiliki gambaran kualitas relasi lingkungan yang baik ketika memiliki fasilitas yang memadai dan merasa puas dengan fasilitas yang dimiliki.

Berdasarkan penelitian yang telah dilakukan, penulis menyarankan orang tua untuk membantu mahasiswa autistik dalam meningkatkan kemampuan komunikasi dan interaksi dengan orang lain melalui terapi maupun media lain. Universitas pun dapat menyediakan fasilitas pelatihan dan pengembangan sosial melalui program inklusi bagi mahasiswa autistik. Kemudian, universitas sebaiknya juga membuat program atau pelatihan bagi tenaga pendidik, terutama dosen, sebagai upaya dalam memberikan wawasan dan informasi tambahan mengenai individu autistik, termasuk di dalamnya bagaimana cara memperlakukan mereka.

Bagi peneliti selanjutnya, penulis menyarankan untuk meneliti aspek lain mengenai mahasiswa autistik, seperti kebutuhan selama di kampus, kendala yang dihadapi selama di kampus, aktualisasi diri mahasiswa autistik, dan sebagainya. Ketika melaksanakan penelitian, penulis menyarankan untuk menggunakan metode penelitian lain yang dinilai lebih tepat dalam membahas aspek tertentu mengenai mahasiswa autistik dan lebih memperdalam data yang diteliti.

\section{U C A P A N T E R I M A K A S I H}

Penulis mengucapkan terima kasih kepada psikolog dan sejawat keilmuan yang banyak memberikan pandangan baru dan saran dalam setiap diskusi yang dilakukan. Semoga kita dapat berdiskusi kembali mengenai khazanah keilmuan psikologi.

\section{DEKLARAS I POTENSI TERJADINYA KONFLIK KEPENTINGAN}

Muthi'ah Amah Al Rahim dan Ika Yuniar Cahyanti tidak bekerja, menjadi konsultan, memiliki saham, atau menerima dana dari perusahaan atau organisasi manapun yang mungkin akan mengambil untung dari diterbitkannya naskah ini.

\section{PUSTAKA ACUAN}

Adreon, D., \& Durocher, J. S. (2007). Evaluating the college transition needs of individuals with highfunctioning autism spectrum disorders. 42(5), 271-279.

Bishop-Fitzpatrick, L., Minshew, N. J., \& Eack, S. M. (2013). A systematic review of psychosocial interventions for adults with autism spectrum disorders. 43(3), 687-694. https://doi.org/10.1007/s10803-012-1615-8

Cullen, J. A. (2015). The needs of college students with autism spectrum disorders and asperger's syndrome. 28(1), 89-101.

DePape, A.-M., \& Lindsay, S. (2016). Lived experiences from the perspective of individuals with autism spectrum disorder: A qualitative meta-synthesis. 31(1), 60-71. https://doi.org/10.1177/1088357615587504 
Elsabbagh, M., Divan, G., Yun-Joo, K., Kim, Y. S., Kauchali, S., Marcin, C., Montiel-Nava, C., Patel, V., Paula, C. S., Wang, C., Yasamy, M. T., \& Fombonne, E. (2012). Global prevalence of autism and other pervasive developmental disorders. 5(3), 160-179. https://doi.org/10.1002/aur.239

Gelbar, N. W., Smith, I., \& Reichow, B. (2014). Systematic review of articles describing experience and supports of individuals with autism enrolled in college and university programs. 44, 2593-2601. https://doi.org/10.1007/s10803-014-2135-5

Graetz, J., \& Spampinato, K. (2008). Asperger's syndrome and the voyage through high school: Not the final frontier. 198, 19-24.

Hong, J., Bishop-Fitzpatrick, L., Smith, L. E., Greenberg, J. S., \& Mailick, M. R. (2016). Factors associated with subjective quality of life of adults with autism spectrum disorder: Self-report versus maternal reports. 46, 1368-1378. https://doi.org/10.1007/s10803-015-2678-0

Jackson, S. L., Hart, L., Brown, J. T., \& Volkmar, F. R. (2018). Brief report: Self-reported academic, social, and mental health experiences of post-secondary students with autism spectrum disorder. 48(3), 643-650. https://doi.org/10.1007/s10803-017-3315-x

Kamp-Becker, I., Schröder, J., Remschmidt, H., \& Bachmann, C. J. (2010). Health-related quality of life in adolescents and young adults with high functioning autism-spectrum disorder. 7, 1-10.

Kementerian Kesehatan Republik Indonesia. (2012, April 16). Kemenkes peringati hari autis international. Kementerian Kesehatan Indonesia. https://www.kemkes.go.id/article/view/1881/kemenkes-peringati-hari-autisinternational.html

Kementerian Kesehatan Republik Indonesia. (2016, April 4). Kenali dan deteksi dini individu dengan spektrum autisme melalui pendekatan keluarga untuk tingkatkan kualitas hidupnya. Direktorat Kesehatan Keluarga. http://kesga.kemkes.go.id/berita-lengkap.php?id=11-

Levy, A., \& Perry, A. (2011). Outcomes in adolescents and adults with autism: A review of the literature. 5(4), 1271-1282.

Mason, D., McConachie, H., Garland, D., Petrou, A., Rodgers, J., \& Parr, J. R. (2018). Predictors of quality of life for autistic adults. 11, 1138-1147. https://doi.org/10.1002/aur.1965

Matadjo, A. A. D. (2019, April 7). Penanganan anak autistik dan manifestasinya ketika dewasa [Personal communication].

Moss, P., Mandy, W., \& Howlin, P. (2017). Child and adult factors related to quality of life in adults with autism. 47, 1830-1837. https://doi.org/10.1007/s10803-017-3105-5 
Pillay, Y., \& Bhat, C. (2012). Facilitating support for students with asperger's syndrome. 26(2), 140-154.

Poerwandari, E. K. (2017). Pendekatan kualitatif untuk penelitian perilaku manusia. LPSP Fakultas Psikologi Universitas Indonesia.

Pugliese, C. E., \& White, S. W. (2014). Brief report: Problem solving therapy in college students with autism spectrum disorders: Feasibility and preliminary efficacy. 44, 719-729. https://doi.org/10.1007/s10803-013-1914-8

Russell, G., Kapp, S. K., Elliott, D., Elphick, C., Gwernan-Jones, R., \& Owens, C. (2019). Mapping the autistic advantage from the accounts of adults diagnosed with autism: A qualitative study.1(2), 124-134. https://doi.org/10.1089/aut.2018.0035

Shattuck, P. T., Steinberg, J., Yu, J., XinWei, Cooper, B. P., Newman, L., \& Roux, A. M. (2014). Disability identification and self-efficacy among college students on the autism spectrum. 2014, 1-7. https://doi.org/10.1155/2014/924182

Sosnowy, C., Silverman, C., Shattuck, P. T., \& Garfield, T. (2018). Setbacks and successes: How young adults on the autism spectrum seek friendship. 1(1), 1-8. https://doi.org/10.1089/aut.2018.0009

Starman, A. B. (2013). The case study as a type of qualitative research. 1, 28-43.

Sugiyono. (2015). Metode penelitian pendidikan: Pendekatan kuantitatif, kualitatif dan R\&D. Alfabeta.

Van Hees, V., Moyson, T., \& Roeyers, H. (2015). Higher education experiences of students with autisme spectrum disorder: Challenges, benefits, and support needs. 45, 1673-1688. https://doi.org/10.1007/s10803-014-2324-2

Volkmar, F. R., Jackson, S. L., \& Hart, L. (2017). Transition issues and challenges for youth with autism spectrum disorders. 46(6), e219-e223. https://doi.org/10.3928/19382359-20170519-03

White, S. W., Elias, R., Salinas, C. E., Capriola, N., Conner, C. M., Asselin, S. B., Miyazaki, Y., Mazefsky, C. A., Howlin, P., \& Getzel, E. E. (2016). Students with autism spectrum disorder in college: Results from a preliminary mixed methods: Needs Analysis. 56, 29-40. https://doi.org/10.3928/1938235920170519-03.

WHOQOL Group. (1998). Development of the world health organization WHOQOL-BREF quality of life assessment. 28, 551-558.

World Health Organization. (2018, April 2). Autism spectrum disorders. World Health Organization. https://www.who.int/news-room/fact-sheets/detail/autism-spectrum-disorders 